\title{
ARTIKELEN
}

\section{Het monstertruckdrama in Haaksbergen en het vertrek van burgemeester Gerritsen ${ }^{*}$}

\author{
Sandra L. Resodihardjo, Marloes Meijer \& Brendan J. Carroll
}

\begin{abstract}
Het verantwoordingsproces na een crisis kan heftig verlopen. Tijdens dit proces proberen actoren de blaam weg te schuiven of te marginaliseren, zodat zij niet hoeven op te stappen. Dit gebeurde ook in 2014 toen een monstertruck het publiek inreed tijdens een festival in Haaksbergen. Als gevolg hiervan overleden drie mensen en raakten velen (zwaar)gewond. Naar aanleiding van dit drama kwamen vier hoofdrolspelers (de truckchauffeur, de burgemeester, de gemeente en de evenementorganisatie) onder vuur te liggen. Uiteindelijk trad de burgemeester af. Zijn defensieve houding dat de vergunning ook met de kennis van nu weer afgegeven zou worden, speelde daarbij een rol.
\end{abstract}

\section{Inleiding}

Op 28 september 2014 reed een monstertruck het publiek in tijdens een autoevenement in Haaksbergen. Hierdoor overleden drie mensen en raakten er tientallen mensen (zwaar)gewond (Tubantia, 2014a; NRC Handelsblad, 2015). Zoals vaker na een gruwelijke gebeurtenis werden er naar aanleiding van dit drama al snel vragen gesteld over hoe dit had kunnen gebeuren en wie er verantwoordelijk was. Al snel richtte de aandacht zich op de bestuurder van de monstertruck (D.), de organisator van het evenement (Stichting Sterevenementen), de gemeente Haaksbergen en de burgemeester van Haaksbergen (Gerritsen).

De kritiek op deze actoren was soms heftig, waarbij een discussie ontstond wie waar verantwoordelijk voor was. Daarbij werd niet geschroomd om de blaam bij een ander neer te leggen. De discussie vertoont daarmee alle kenmerken van een blame game (zwartepieten): actoren worden ervan beschuldigd dat zij een ongeluk mede hebben veroorzaakt en in reactie hierop proberen zij de blaam te ontkennen, te verminderen of weg te schuiven, om zo zonder al te veel kleerscheuren uit de discussie te komen.

In dit geval eindigde de blame game met het aftreden van burgemeester Gerritsen. Maar waarom moest de burgemeester uiteindelijk vertrekken? Om deze vraag te beantwoorden, maken we gebruik van de blame game literatuur. Deze literatuur stelt ons in staat om de krantenartikelen over het monstertruck-drama

* De auteurs willen de reviewers en de deelnemers aan (panels van) de NIG conferentie, de PSA conferentie en de work-in progress rond veiligheid en crisis-bijeenkomst bedanken voor hun waardevolle feedback. 
te coderen en te analyseren om zo in kaart te brengen hoeveel blaam de belangrijkste actoren in de blame game toegeschoven kregen en hoe zij reageerden op deze blaam. In dit artikel zullen wij eerst de literatuur en de gebruikte onderzoeksmethoden bespreken, waarna wij ingaan op de gebeurtenissen.

\section{Blame game - de theorie}

Framing speelt een belangrijke rol in blame games. Allereerst moet namelijk vastgesteld worden of een gebeurtenis een crisis is of niet. Alhoewel sommige gebeurtenissen (zoals Chernobyl) duidelijk een crisis zijn, zal over andere gebeurtenissen eerst gediscussieerd moeten worden om tot een consensus te komen dat cruciale normen en waarden in de maatschappij onder druk zijn komen te staan en dus gesproken kan worden van een crisis ('t Hart, 1993; Brändström en Kuipers, 2003; Boin, 't Hart en McConnell, 2009).

Als de gebeurtenis eenmaal geframed is als een crisis, dient ook de oorzaak van de crisis geframed te worden. Hadden we hier te maken met een gebeurtenis die niet te voorzien en te voorkomen was of kan iemand of een organisatie aangewezen worden die de crisis had moeten voorkomen?

De vraag is dan hoeveel blaam die persoon of organisatie toegeworpen krijgt. Dit hangt af van een aantal factoren: (a) de reputatie van deze actor voor de crisis, een slechte reputatie maakt het makkelijker om deze actor aan te vallen; (b) of een soortgelijke gebeurtenis zich heeft voorgedaan in het verleden, want dan had men moeten leren van die gebeurtenis; (c) de mate waarin de actor heeft bijgedragen aan de crisis; en (d) hoeveel te voorkomen schade er is geleden (Coombs, 2007: 141-3; Hood, 2011: 6). Ook nieuwe informatie en de manier waarop actoren reageren op blaam beïnvloeden hoeveel blaam ze krijgen toegeworpen (Resodihardjo et al., 2016). Hood et al. (2009) onderscheiden vijf blaamniveaus: neutraal/positief (neutrale berichtgeving met soms positieve noten), licht kritisch (positieve/neutrale berichtgeving met hier en daar wat kritiek), gemixt (kritische berichtgeving wordt dominanter), grotendeels negatief (voornamelijk kritische berichtgeving) en zeer negatief (zeer kritische berichtgeving waarbij bijvoorbeeld wordt geroepen om het aftreden van een actor).

Hood (2011) geeft aan dat actoren drie strategieën hebben om om te gaan met deze blaam. Twee van deze strategieën dienen al geactiveerd te zijn voordat de crisis plaatsvindt. Dit zijn beleidsstrategieën (waarbij bij beleidsimplementatie bijvoorbeeld gebruik wordt gemaakt van protocollen waar men op kan terugvallen als er kritiek is) en uitvoeringsorganisatiestrategieën (waarbij blaam bijvoorbeeld verschoven kan worden naar een zelfstandig bestuursorgaan). Mochten deze strategieën niet aanwezig zijn of niet werken, dan kan men terugvallen op de presentatiestrategieën.

Presentatiestrategieën zijn strategieën waarbij voornamelijk retoriek wordt gebruikt om anderen te overtuigen dat er bijvoorbeeld geen probleem is, dat de schade minder erg is dan gedacht, dat er omstandigheden zijn die verklaren waarom dit heeft kunnen gebeuren en dat iemand anders de schuld moet krijgen. Daarnaast kan men zich onder meer verontschuldigen, ontslag nemen, de slacht- 
offers helpen en/of een onderzoek instellen (McGraw, 1990; Hood et al., 2009; Benoit, 1997; Ihlen, 2002; Coombs, 2007). Presentatiestrategieën omvatten een breed scala aan reacties - van uiterst defensief (er is geen crisis) tot uiterst accommoderend (wij zijn verantwoordelijk en we gaan dit probleem oplossen). Een aantal auteurs geeft aan dat zij verwachten dat hoe hoger de blaam is, hoe meer de blaamrespons moet tegemoetkomen aan deze blaam, wil de blaam uiteindelijk afnemen (Hearit, 2001: 509; Ihlen, 2002: 191; Coombs, 2007: 143; Hood et al., 2009). Met andere woorden, een te defensieve reactie kan ertoe leiden dat men nog bozer wordt op de actor die reeds onder vuur ligt. Men hoeft echter niet te accommoderend te zijn, door op te stappen wanneer het blaamniveau nog laag is. Het is dus belangrijk een goede match te vinden tussen hoeveel blaam men toegeschoven krijgt en hoe defensief/accommoderend de reactie moet zijn. Tegelijkertijd moet er aandacht worden besteed aan de slachtoffers en moet er een duidelijk signaal worden afgegeven dat er geleerd zal worden van deze gebeurtenis (Ihlen, 2002: 191). In de volgende paragraaf leggen we uit hoe we het blaamniveau en de blaamrespons hebben onderzocht.

\section{Onderzoeksmethodologie}

Voor dit onderzoek zijn krantenartikelen uit vier kranten gecodeerd: drie nationale kranten die samen een breed spectrum aan opinies vertegenwoordigen ( $D e$ Telegraaf, de Volkskrant en het NRC Handelsblad) en een regionale krant (Tubantia). Voor de periode 28 september 2014 (dag van het ongeval) tot en met 31 mei 2015 (de laatste dag van de maand waarin de burgemeester is afgetreden) zijn in LexisNexis krantenartikelen geselecteerd over het ongeval met behulp van de zoekterm 'monstertruck Haaksbergen'. Dit resulteerde in 325 artikelen. Na verwijdering van dubbele en ongeschikte artikelen (ingezonden brieven en artikelen waarin het ongeval als illustratie wordt gebruikt of waarin de actoren van de blame game niet worden genoemd, omdat de focus ligt op slachtoffers en nabestaanden) resteerden 156 artikelen.

Op basis van Hood et al. (2009) is een codeboek gemaakt. Twee auteurs hebben alle krantenartikelen afzonderlijk gecodeerd met behulp van dit codeboek. Per krantenartikel is gekeken hoeveel actoren genoemd worden die betrokken waren bij de blame game. Voor elke actor werd vervolgens vastgesteld hoeveel blaam deze kreeg volgens de eerder beschreven blaamniveaus van Hood, waarbij 0 werd toegekend in gevallen dat het artikel puur beschrijvend is. Bij meerdere niveaus van blaam werd het hoogste blaamniveau gecodeerd. Ook de blaamreactie van de actor werd gecodeerd ( 0 indien er niets wordt geschreven over de reactie van de actor; $1 \mathrm{t} / \mathrm{m} 9$ voor de reacties zoals beschreven in tabel 1, en 10 wanneer een oude blaamrespons werd beschreven). Als in een artikel meerdere soorten blaamreacties werden gegeven door een actor, werd de blaamrespons gecodeerd met de code van de blaamreactie die het sterkst aanwezig was in het artikel. Als de verschillende blaamreacties even sterk aanwezig waren in het artikel, werd de code voor de hoogste aanwezige blaamrespons toegekend. De keuze voor het coderen van de hoogste blaamrespons en het hoogste blaamniveau in het geval 
Tabel 1 De verschillende blaamreacties volgens Hood c.s. (2009: 698)

\begin{tabular}{l|l|}
\hline Code & Blaamrespons \\
\hline $\mathbf{1}$ & Ontkennen dat er een probleem is \\
\hline $\mathbf{3}$ & Erkennen dat er iets kleins aan de hand is \\
\hline 4 & Naast ontkenning wordt ook een tegenaanval op critici uitgevoerd \\
\hline 5 & $\begin{array}{l}\text { 'Open houding over wie verantwoordelijk is' (er is een onderzoek nodig om } \\
\text { dat vast te stellen) }\end{array}$ \\
\hline 6 & De blaam wegschuiven naar anderen \\
\hline 7 & Gedeeltelijke maar niet complete verantwoordelijkheid nemen \\
\hline 8 & Uitleg geven 'zonder verantwoording te accepteren' \\
\hline 9 & Institutionele reactie zoals schadevergoeding uitkeren \\
\hline
\end{tabular}

van meerdere reacties is ingegeven door de theorie die ervan uitgaat dat hoe hoger de blaam, hoe meer accommoderend men moet zijn in de reactie hierop. Deze hypothese kan alleen getoetst worden als in dergelijke gevallen de hoogste scores worden gecodeerd.

De auteurs codeerden de artikelen eerst alleen en vergeleken daarna de coderingen. De eerste veertig artikelen vormden de pilotstudy om het coderen te trainen; deze artikelen zijn onderdeel van de gecodeerde dataset. Op basis van de overige artikelen (116) kan gesteld worden dat de intercodeurbetrouwbaarheid $91,2 \%$ is en dat de overeenstemming over de toegekende coderingen na discussie $98,6 \%$ is. Met behulp van de krantenartikelen en andere relevante bronnen is een uitgebreide casusbeschrijving gemaakt. De betreffende bronnen zijn de vergunning, de verslagen van de Commissie bezwaarschriften en de Onderzoeksraad voor Veiligheid, een uitgeschreven toespraak van de burgemeester en de audio-opnames van de twee gemeenteraadsvergaderingen. Een korte samenvatting van deze casusbeschrijving wordt in de volgende paragraaf gepresenteerd. Hierin worden chronologisch de belangrijkste gebeurtenissen beschreven.

\section{Het monstertruck-ongeval}

Op 28 september 2014 vond in Haaksbergen het evenement AutoMotorSportief plaats op het parkeerterrein van Jumbo (Colijn, 2014a; Tubantia, 2014f), waarbij een monstertruck over zes sloopauto's reed. De monstertruckchauffeur was echter niet in staat voldoende af te remmen nadat hij over de autowrakken was gereden en reed het publiek in. Drie mensen overleden, waaronder een jongetje van vijf (Dohmen en Toonen, 2014; Colijn, 2014c). Daarnaast raakten tientallen mensen (zwaar)gewond (Tubantia, 2014a).

De dag na het ongeval werd door omstanders en experts al gespeculeerd over mogelijke oorzaken van het ongeval (zoals stuurproblemen en een kapotte remlei- 
ding) (Colijn, 2014a; Dohmen en Toonen, 2014). Tevens werd kritiek geleverd op de locatie van het evenement: het terrein zou te klein zijn, er was te weinig afstand tussen de monstertruck en het publiek, er stonden alleen dranghekken tussen de truck en het publiek en het publiek stond in de rijrichting van de monstertruck - wat volgens internationale voorschriften nooit had mogen gebeuren (Dohmen en Toonen, 2014; Colijn, 2014a; de Volkskrant, 2014; Tubantia, 2014a). De gemeente maakte dezelfde dag de vergunning voor het evenement openbaar (Timmers, 2014a). Hieruit bleek dat de vergunning vier dagen voor het evenement was afgegeven (de Volkskrant, 2014) en uit iets meer dan twee A4 bestond (Timmers, 2014a). De veiligheidsvoorschriften besloegen niet meer dan één alinea waarin werd gesteld dat er 'een "deugdelijke voorziening" [moet] worden getroffen' - te weten dranghekken die mensen op 10 meter afstand moeten houden (Timmers, 2014a). Nergens stond echter uitgelegd vanaf welk punt die 10 meter begon (Timmers, 2014a).

De burgemeester gaf aan niet op de hoogte te zijn van de inhoud van de vergunning (Schreuder en Toonen, 2014) en dat Stichting Sterevenementen de gemeente niet had geïnformeerd over de monstertruckstunt. Daarom had de gemeente de vergunningaanvraag op dezelfde manier behandeld als eerdere aanvragen van Sterevenementen. Omdat de vergunningaanvraag van het evenement als reguliere aanvraag was behandeld, was de aanvraag afgehandeld door een gemandateerde ambtenaar en niet bekeken door het college van burgemeester en wethouders. Ook de politie en brandweer hadden niet gekeken naar deze aanvraag, omdat hun advies niet hoeft te worden ingewonnen bij evenementen tot 2.500 bezoekers (Tubantia, 2014b). De directeur van Stichting Sterevenementen reageerde dat de gemeente wel degelijk was geïnformeerd (Colijn, 2014b). De gemeente stelde zelf een onderzoek in om helder te krijgen hoe de vergunning was verleend (Colijn, 2014b). Daarnaast maakte de Onderzoeksraad voor Veiligheid op 30 september bekend het ongeval te onderzoeken, zodat daarvan geleerd kon worden (Timmers, 2014b).

Omdat de vergunning zo recent was afgegeven, was het mogelijk een bezwaarschrift tegen de vergunning in te dienen - ook al had het evenement al plaatsgevonden. Begin oktober werd namens enkele slachtoffers een aantal bezwaarschriften ingediend (Tubantia, 2014e, 2014h) om zo te 'voorkomen dat de vergunning formele rechtskracht krijgt, waarna de gemeente niet of nauwelijk[s] meer aansprakelijk is te stellen' (Tubantia, 2014h).

Naar aanleiding van het interne onderzoek en ter voorbereiding op de vergadering van 15 oktober plaatste de gemeente op 10 oktober een feitenoverzicht en een aantal documenten op haar website waaruit onder meer bleek dat vlak voor de show het aantal toeschouwers was opgehoogd (Haaksbergen z.j.; Timmers en Baard, 2014). Desondanks werden politie en brandweer niet om advies gevraagd (Timmers en Baard, 2014).

Op 15 oktober 2014 vond een informele (en dus geen reguliere) raadsbijeenkomst plaats, zodat gesproken kon worden over het ongeluk zonder te hoeven ingaan op de schuldvraag (Tooms, 2014). Tijdens deze bijeenkomst bleven veel vragen onbeantwoord, omdat het college van B\&W de onderzoeken van het OM en de Onderzoeksraad en de uitkomst van de bezwaarschiftprocedure wilde afwachten voor- 
dat op bepaalde vragen kon worden ingegaan (Rouwenhorst, 2014). De raadsleden begrepen dat sommige vragen nog onbeantwoord bleven, aangezien een en ander nog uitgezocht moest worden (Bouwhuis, 2014b; Haaksbergen, 2014).

Op 24 oktober kwamen de verzekeringsmaatschappijen van de gemeente Haaksbergen en Stichting Sterevenementen overeen een noodfonds in te stellen voor slachtoffers met acute geldproblemen. De verzekeringsmaatschappijen wezen wel 'vooralsnog de aansprakelijkheid af' (Tubantia, 2014i).

Op 27 november 2014 werd in een uitzending van Brandpunt Reporter bekendgemaakt dat monstertruckchauffeur D. al eerder een ongeluk had veroorzaakt in Asten door met zijn motor het publiek in te rijden. Hierbij raakten zes mensen gewond, terwijl D. geen aansprakelijkheidsverzekering had. Tijdens de uitzending werd duidelijk dat D. ook voor Haaksbergen geen aansprakelijkheidsverzekering had (Colijn, 2014e). D. ontkende het eerdere ongeval en zei dat mensen elkaar door de drukte 'onder de voet [hadden] gelopen' (Tubantia, 2014l). Een dag later werd bekendgemaakt dat het Waarborgfonds Motorverkeer geld zou uitkeren indien 'slachtoffers (...) met lege handen komen te staan' (Tubantia, 2014k) en dat het fonds daarna het geld zou 'verhalen op de schuldigen' (Baard, 2015b). Zo liet het fonds beslag leggen op eigendommen van D., waaronder zijn monstertruck (Baard, 2015b; Tubantia, 2015a).

De gemeente maakte haar positie omtrent de vergunningverlening duidelijk in haar verweerschrift. Volgens de gemeente waren alle bezwaarschriften onontvankelijk of ongegrond. "Er kleeft hooguit "een zorgvuldigheidsgebrek" aan [de vergunning], omdat niet alle onderdelen van de stunts zijn beoordeeld. Dat betekent niet dat de vergunning geweigerd zou zijn als die afweging wel was gemaakt' (Baard, 2015a). Volgens de gemeente Haaksbergen was de vergunninghouder - Stichting Sterevenementen - verantwoordelijk voor het goed uitvoeren van de vergunningseis van voldoende veiligheidsmaatregelen (Baard, 2015a).

Op 16 februari 2015 (Haaksbergen, 2015a) kwam de bezwaarcommissie met haar advies 'om de vergunning alsnog te weigeren', aangezien er 'onvoldoende zekerheid was dat de veiligheid van de bezoekers van de stuntshow op het parkeerterrein bij Jumbo kon worden gegarandeerd indien zich tijdens de stunts een ongeval zou voordoen' (Talens, 2015). In haar advies stelde zij dat de vergunningsprocedure onzorgvuldig was verlopen en dat Gerritsen 'onrechtmatig [had] gehandeld' (Talens, 2015). Het oordeel van de bezwaarcommissie leidde tot heftige kritiek op burgemeester Gerritsen, waarbij in de Tubantia werd opgemerkt dat Gerritsen politieke verantwoording zou moeten afleggen voor het werk van zijn ambtenaren (Tubantia, 2015b). Gerritsen gaf aan voor 10 maart met een reactie te komen (Talens, 2015). De uiteindelijke reactie van de burgemeester stelde echter veel mensen teleur. De vergunning werd niet ingetrokken, maar gehandhaafd. Sterker nog: 'Haaksbergen zou die [vergunning] ook vandaag, met de kennis van nu over de gang van zaken op die "zwarte zondag", in de afgegeven vorm hebben verstrekt. (...) Dat de show anders is verlopen was in redelijkheid (...) niet te voorzien' (Tubantia, 2015c). Gerritsen maakte ook duidelijk dat hij niet wilde aftreden, maar juist wilde optreden (Tubantia, 2015c).

Op 20 mei 2015 publiceerde de Onderzoeksraad voor Veiligheid haar rapport. Hierin werd kritiek geleverd op gemeente, burgemeester, organisator en chauf- 
feur: allen hadden gefaald in hun taak een veilig evenement te organiseren. De gemeenteambtenaar had niet gekeken naar de inhoud van het programma en de veiligheidsmaatregelen niet getoetst; de burgemeester kon weliswaar de vergunningsbevoegdheid mandateren, maar had gefaald in het 'toets[en] of degene aan wie het mandaat wordt verleend hieraan op de juiste wijze invulling kan geven'; Stichting Sterevenementen had een reactieve houding, waarbij ervan uit werd gegaan dat het stuntteam de veiligheid zou verzorgen en wel aan de bel zou trekken als er iets moest gebeuren (Onderzoeksraad voor Veiligheid, 2015a: 2-4); en het stuntteam had gezien de risico's de stunt niet door mogen laten gaan (Onderzoeksraad voor Veiligheid, 2015b: 6). De Onderzoeksraad uitte stevige kritiek op de vergunningverlening in Haaksbergen, die werd gekenmerkt door 'bestuurlijke en organisatorische verwaarlozing' (Onderzoeksraad voor Veiligheid, 2015a: 5). Deze verwaarlozing in combinatie met het idee dat het evenement onschuldig vermaak betrof, resulteerde in een verkeerde inschatting van het risico van de show (Onderzoeksraad voor Veiligheid, 2015a: 5). Tegelijkertijd gaf de Onderzoeksraad aan dat sommige andere gemeenten ook te weinig expertise en kennis in huis hadden, waardoor het lastig is voor deze gemeentes om een goede risicoinschatting te maken (Onderzoeksraad voor Veiligheid, 2015a: 4).

In reactie op het rapport nam de kritiek in de media op de burgemeester toe. Zo werd een dag na de publicatie al de vraag gesteld of de burgemeester niet moest aftreden, gezien het feit dat hij de eindverantwoordelijke was (Tubantia, 2015e). De burgemeester gaf aan zich niet te herkennen in de conclusie van het rapport dat hij te weinig aandacht zou hebben voor vergunningverlening, maar stelde dat hij het goed vond dat burgemeesters een prominentere rol krijgen in de vergunningverlening (Tubantia, 2015f). Op de vraag of hij nu weer de vergunning zou afgeven, antwoordt de burgemeester bevestigend: 'In principe wel' (Tubantia, 2015f). Hij gaf daarnaast ook aan niet te willen aftreden (Colijn, 2015).

De gemeenteraad kwam op 27 mei 2015 bijeen om het ongeval en het onderzoeksrapport te bespreken. Voorafgaand aan deze vergadering werd duidelijk dat een aantal oppositiepartijen kritisch stond tegenover het functioneren van de burgemeester. De GGH (de Gemeenschappelijke Groepering Haaksbergen) dacht erover een motie van wantrouwen tegen de burgemeester en alle wethouders in te dienen, aangezien het college in reactie op de bezwaarschriftencommissie had gesteld de vergunning toch weer af te geven. De motie van wantrouwen van de VVD zou alleen gericht zijn tegen de burgemeester. In beide gevallen wilden de politieke partijen de reactie van de burgemeester en het college afwachten totdat daadwerkelijk zou worden overgegaan tot het indienen van de moties (Tubantia, 2015g).

Tijdens de gemeenteraadsvergadering bood de burgemeester voor het eerst zijn excuses aan voor de gemaakte fouten (De Telegraaf, 2015; Tubantia, 2015h), maar de gemeenteraadsleden namen het de burgemeester kwalijk dat hij achter de verleende vergunning was blijven staan (Staal en Baard, 2015; zie bijv. Haaksbergen, 2015b: 22.20-23.16). Zij betitelden zijn optreden als 'formeel [juridisch] (...) te weinig zelfreflecterend (...) weinig zelfkritiek (...) te relativerend' (Staal en Baard, 2015). Alle politieke partijen riepen de burgemeester op 'zich te beraden op zijn positie’ (Rouwenhorst, 2015). Tijdens de schorsing van de vergadering 
deed de burgemeester dit inderdaad. Na de schorsing gaf hij aan af te treden (Staal en Baard, 2015; De Telegraaf, 2015).

Op 9 juni 2015 maakte het OM bekend dat D. en Stichting Sterevenementen vervolgd zouden worden 'voor dood door schuld en het veroorzaken van zwaar lichamelijk letsel door schuld' (Openbaar Ministerie, 2015). Over de gemeente Haaksbergen en haar ambtenaren meldde het $\mathrm{OM}$ alleen dat deze niet strafrechtelijk vervolgd kunnen worden (Openbaar Ministerie, 2015). Op 15 april 2016 veroordeelde de rechter $\mathrm{D}$. tot vijftien maanden cel en een werkverbod als stuntman voor vijf jaar, vanwege het nemen van onacceptabele risico's (NRC Handelsblad, 2016). Ook werd hem zijn monstertruck afgenomen (Tubantia, 2016a). Stichting Sterevenementen kreeg een voorwaardelijke boete van $€ 25.000$ opgelegd, omdat zij 'haar "zorgplicht verwijtbaar veronachtzaamd"' had (NRC Handelsblad, 2016). D. ging in beroep tegen de uitspraak (Tubantia, 2016b). Tijdens het schrijven van dit artikel was de uitkomst van het hoger beroep nog niet bekend.

\section{De blame game na het ongeval}

$\mathrm{Nu}$ de belangrijkste gebeurtenissen zijn beschreven, zullen we inzoomen op de blame game. $\mathrm{Na}$ een grafische weergave in de figuren $1 \mathrm{~A}$ tot en met $1 \mathrm{D}$ beschrijven we kort het blaamniveau en de reacties van de vier hoofdrolspelers in de blame game alvorens te focussen op het handelen van de burgemeester.

\section{Figuren 1A-1D Blaamniveaus en blaamreacties van de vier actoren}

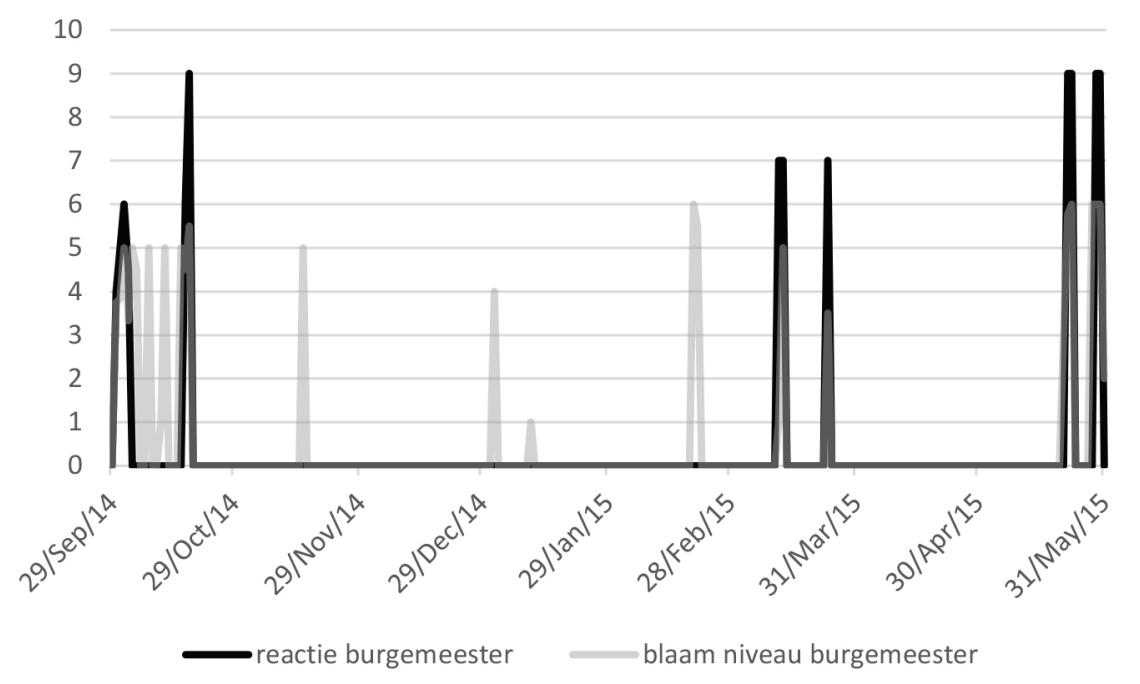

Figuur $1 A$ 


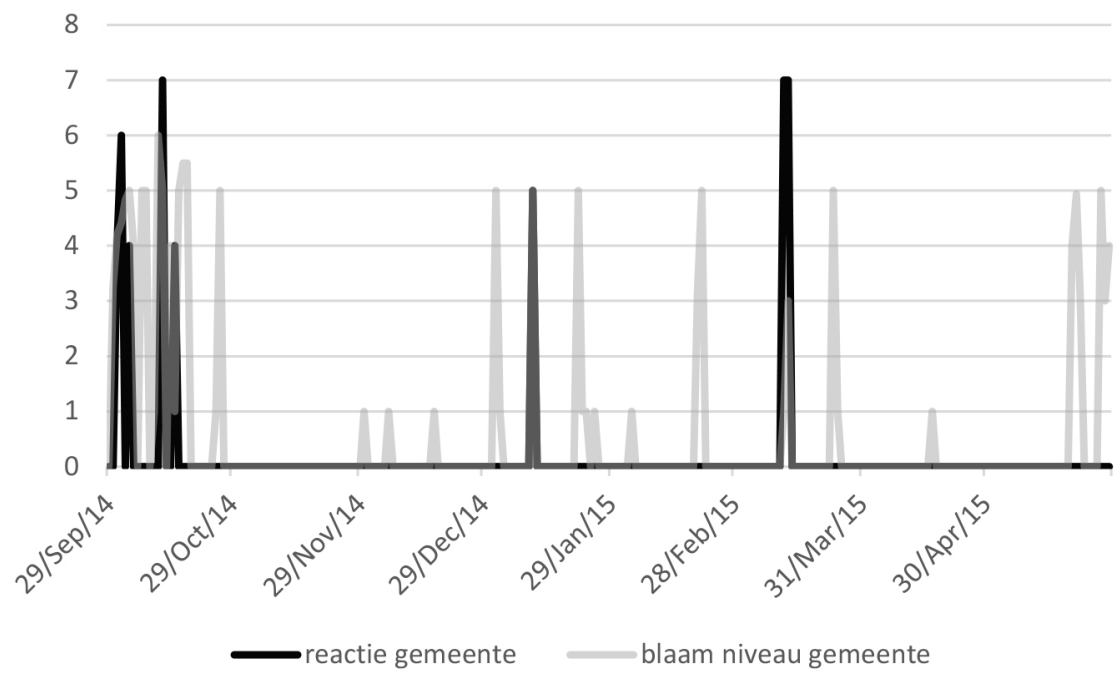

Figuur 1B

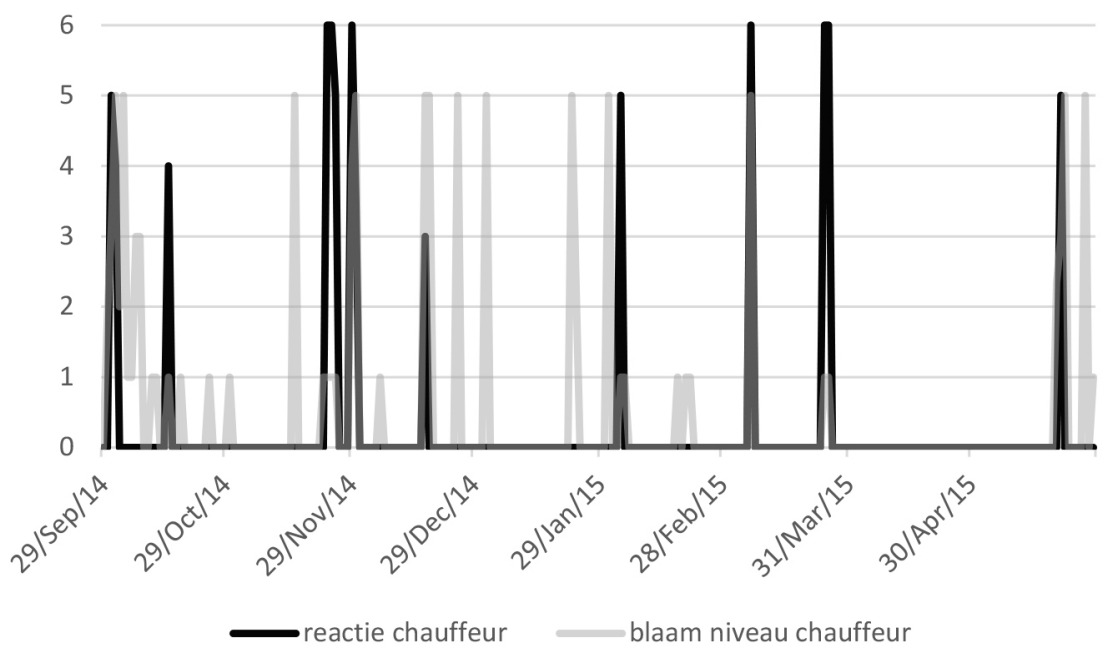

Figuur $1 C$ 


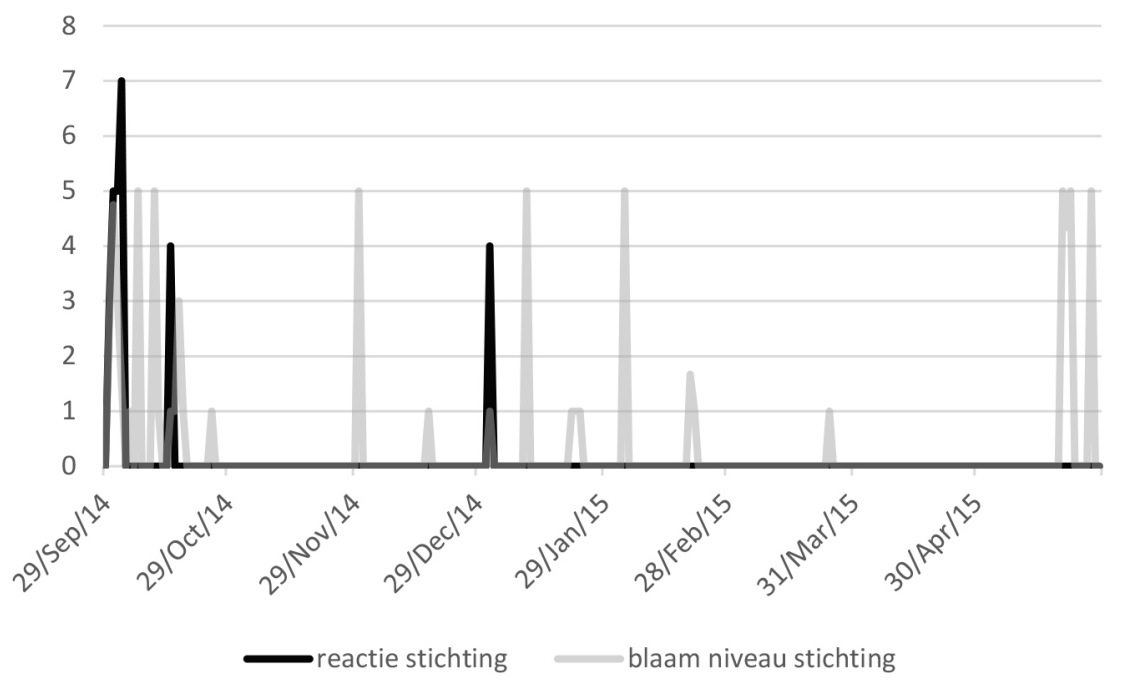

Figuur 1D

De figuren 1A tot en met 1D laten zien hoeveel blaam de vier belangrijkste actoren ontvingen en hoe ze hierop reageerden. Om onderscheid te maken tussen dagen waarop kranten geen aandacht besteden aan actoren en dagen waarop weliswaar aandacht wordt besteed aan actoren, maar er geen blaam wordt toegekend aan de betreffende actor of de betreffende actor geen blaamrespons geeft, is figuur 1 gemaakt door alle coderingen met 1 te verhogen. Daardoor staat 0 in de figuur nu voor 'actor wordt niet genoemd'; 1 voor 'actor wordt wel genoemd maar er wordt geen blaam aan de actor toegekend/de actor geeft geen blaamrespons'; 2 voor 'het laagste blaamniveau/blaamrespons', enzovoort.

Uit het figuur wordt duidelijk dat alle vier de actoren te maken hadden met een hoog blaamniveau. Zij reageerden echter niet altijd op deze blaam. Als men al reageerde, dan gebruikte men niet de meest defensieve tactiek: het ontkennen van de crisis.

Een tactiek die alle vier de hoofdrolspelers wel hebben gebruikt - maar zonder resultaat - is het proberen te verschuiven van de blaam naar een andere actor. Zo gaf de burgemeester aan dat zijn gemeente niet op de hoogte was gesteld door Stichting Sterevenementen dat er een monstertruck mee zou doen aan het evenement (Tubantia, 2014b). Toen duidelijk werd dat de stichting wel degelijk de gemeente had geïnformeerd, reageerde burgemeester Gerritsen met de opmerking: 'Men maakt weliswaar melding van de komst, maar niet duidelijk wordt wat deze nu precies gaat doen. Het document is op meerdere manieren interpreteerbaar' (Tubantia, 2014c). Stichting Sterevenementen reageerde dat de ambtenaren waren geïnformeerd over de aanwezigheid van de monstertruck (Colijn, 2014b) en dat 'de stuntteams altijd zelf aangeven hoeveel ruimte ze nodig hebben' (de Volkskrant, 2014). Stichting Sterevenementen had zich gehouden aan de voorwaarden van de gemeente en het stuntteam (de Volkskrant, 2014). De chauffeur 
dacht dat het gas was blijven hangen en vond het belangrijk dat tot de bodem werd uitgezocht wat er was gebeurd, maar dat het testen van zijn truck door het $\mathrm{OM}$ op een ondeskundige manier was gebeurd. Hij concludeerde: '[D]e waarheid is nu niet meer te achterhalen' (Tubantia, 2014j). Hij gaf ook aan dat Stichting Sterevenementen de verzekering had moeten regelen (Tubantia, 2014k).

Om te begrijpen waarom burgemeester Gerritsen uiteindelijk moest opstappen, is het belangrijk stil te staan bij de grote variëteit aan rollen die een burgemeester moet vervullen. Zo zijn burgemeesters onder meer bestuurder, burgervader, verbinder, bewaker van de openbare orde, boegbeeld van de gemeente en verantwoordelijke voor 'het door hem gevoerde bestuur' (art. 180 Gemeentewet; Sackers, 2010; Karsten, Schaap en Hendriks, 2014; Nederlands Genootschap van Burgemeesters, 2017). Het is aan burgemeesters om een balans te vinden tussen deze verschillende rollen en te schakelen van de ene rol naar de andere waar nodig. Het balanceren en schakelen is echter geen gemakkelijke klus - zeker niet als er sprake is van een rollenconflict (Sackers, 2010; Karsten, Schaap en Verheul, 2010; Karsten, Schaap en Hendriks, 2014; Nederlands Genootschap van Burgemeesters, 2017; Jong, 2017). Zo wijst Sackers (2010) er bijvoorbeeld op dat 'er soms wel eens fricties zijn tussen de streng, maar rechtvaardig handhavende burgemeester en de begripvolle en innemende burgervader' (p. 91). Uit onderzoek is gebleken dat burgemeesters dit rollenconflict met name ervaren in situaties waar sprake is van een crisis die een grote impact heeft op de gemeenschap, terwijl de burgemeester tegelijkertijd politieke verantwoording moet afleggen over deze crisis en/of hoe deze gemanaged is (Jong, 2017).

De situatie in Haaksbergen werd ook gekenmerkt door een crisis met een grote maatschappelijke impact waarover de burgemeester verantwoording moest afleggen (Nederlands Genootschap van Burgemeesters, 2017: 26; vgl. Meerenburgh en Van Duin, 2015). Het is daarom niet vreemd dat Gerritsen te maken had met rollenconflicten. In zijn geval conflicteerden zowel zijn boegbeeld- als bestuurdersrol met de rol van burgervader.

De burgemeester was helder over '[z]ijn prioriteiten (...): “er zijn” voor slachtoffers en nabestaanden' (Louwes, 2014). Hij bezocht onder andere slachtoffers en nabestaanden en nam deel aan een stille tocht (Louwes, 2014; Tubantia, 2014d). Gerritsen stapte daarmee vol in zijn rol als burgervader. Uit de krantenberichten wordt duidelijk dat Gerritsen ook in die rol werd gewaardeerd (Tubantia, 2014f). Maar over zijn functioneren in de media waren de geluiden kritischer. Zijn mediaoptreden werd als 'niet sterk' en 'niet erg gelukkig' bestempeld, waarbij zijn opmerking dat hij niets wist van een monstertruck weer leidde tot nieuwe discussie, aangezien er overal in het dorp affiches hingen (Bouwhuis, 2014a; vgl. Tubantia, 2014g). Ook moest de burgemeester terugkomen op zijn uitspraak dat bij de gemeente niet bekend was dat er een monstertruck aanwezig zou zijn (Tubantia, 2014c). Gerritsen erkende dat het lastig was om te schakelen van burgervader naar boegbeeld van de gemeente (Rouwenhorst, 2014). Hij beschreef zichzelf daarbij als 'meer burgervader (...), dan mediastrateeg' (Tooms, 2014).

Zoals al eerder werd aangegeven, werd Gerritsen als burgervader gewaardeerd (Tubantia, 2014f) - zelfs na diens aftreden (Rouwenhorst, 2015; Staal en Baard, 2015). Maar de krantenartikelen laten zien dat in de loop van het proces ergernis 
begon te ontstaan toen de burgemeester volhield dat de vergunning opnieuw afgegeven zou worden - zelfs met de kennis van nu. Hierdoor heerste het gevoel dat de burgemeester zijn burgers liet vallen (Tubantia, 2015d). Overigens is op basis van de krantenartikelen niet te achterhalen waarom de burgemeester zo lang bleef volhouden dat de vergunning opnieuw zou worden verleend. In een aantal krantenartikelen en tijdens de tweede raadsvergadering werd wel gespeculeerd over mogelijke schadeclaims die zouden volgen als de burgemeester zou erkennen dat de vergunning inderdaad niet afgegeven had mogen worden (Tubantia, 2015d; Staal en Baard, 2015; De Telegraaf, 2015; Haaksbergen, 2015b). Uit de kranten wordt wel duidelijk dat het problematisch was dat er geen verantwoordelijkheid werd genomen voor wat er was gebeurd. Had de burgemeester dit gedaan, dan zou de burgemeester 'onderstreept [hebben] dat het gemeentebestuur van Haaksbergen begrijpt dat het ernstig tekort is geschoten' (Tubantia, 2015e). Immers, 'zijn burgers verwachten een gebaar dat de gemeenschap in staat stelt verder te gaan' (Tubantia, 2015h). Al met al zien we hier een rollenconflict tussen burgervader en bestuurder. Het luisterend oor van de burgervader botste met de formeel-juridische houding die burgemeester Gerritsen vanuit zijn rol als bestuurder aannam. Het feit dat de burgemeester de vergunning bleef steunen, raakte de mensen diep en het is dus niet vreemd dat zij niet positief waren over de rol van de Gerritsen als 'bestuurder en burgemeester' (Staal en Baard, 2015).

Die defensieve houding ten aanzien van de vergunning - terwijl zijn blaamniveau almaar toenam - kan helpen verklaren waarom de burgemeester uiteindelijk aftrad. Volgens de blame game-theorie dient de blaamrespons afgestemd te zijn op de mate van blaam die men krijgt toegeworpen. Gebeurt dit niet, dan leidt dit juist tot een toename van het blaamniveau met als mogelijk gevolg een (gedwongen) aftreden. In dit geval wordt uit de krantenartikelen en de audio-opname van de tweede gemeenteraadsvergadering duidelijk dat er niet alleen frustratie bij burgers, maar ook bij gemeenteraadsleden heerste over het feit dat de burgemeester de vergunning bleef verdedigen (zie bijv. NRC Handelsblad, 2015). En alhoewel hij niet meer expliciet tijdens deze raadsvergadering zei dat de vergunning ook met de kennis van nu weer afgegeven zou worden - hij gaf alleen aan dat het nu aan de bestuursrechter was om een oordeel te vellen (Haaksbergen, 2015b: 5.10-5.50) - gaf coalitiefractievoorzitter Oltwater ( $\operatorname{PvdA})$ aan dat 'tot op heden' de burgemeester de vergunning bleef verdedigen (Haaksbergen, 2015b: 22.15-22.33). Oltwater - een partijgenoot van de burgemeester (Staal en Baard, 2015) - stelde dan ook: 'Je kan niet het onverdedigbare verdedigen op formele gronden’ (Haaksbergen, 2015b: 23.27- 23.32).

\section{Conclusie}

In dit artikel zijn we op zoek naar een antwoord op de vraag waarom de burgemeester van Haaksbergen moest aftreden naar aanleiding van het monstertruckongeval. De literatuur geeft ons daarvoor belangrijke aanknopingspunten, omdat deze veronderstelt dat hoe hoger het blaamniveau is waar men mee te maken 
heeft, hoe meer accommoderend de blaamreactie moet zijn. Alleen dan zal het blaamniveau afnemen. Blijft de reactie te defensief, dan zal dit volgens de theorie juist wrevel opwekken, wat resulteert in hogere blaamniveaus. Juist dit laatste is terug te zien in deze casus: de burgemeester bleef te defensief gezien zijn blaamniveau, wat weer resulteerde in een stijging van zijn blaamniveau.

Tegelijkertijd laat ons onderzoek zien dat er sprake was van een rollenconflict, wat niet vreemd was, aangezien er een crisis met een grote maatschappelijke impact had plaatsgevonden waarover politieke verantwoording moest worden afgelegd. Gezien de waardering die burgers hadden voor het optreden van Gerritsen als burgervader, kan gesteld worden dat die rol hem goed af ging. Maar deze rol botste met zijn rollen als boegbeeld en bestuurder. Het eerste rolconflict had te maken met het feit dat Gerritsen het lastig vond te schakelen tussen burgervader en boegbeeld. Het tweede rolconflict had mogelijk te maken met het feit dat slachtoffers en nabestaanden zich graag gezien en gehoord willen voelen na een tragedie (cf. Ihlen, 2002). Enerzijds werd aan deze behoefte voldaan door de burgemeester in zijn rol als burgervader. Anderzijds werd deze behoefte genegeerd door de formeel-juridische houding van de burgemeester ten aanzien van de vergunning, een houding die zorgde voor ongeloof bij burgers en gemeenteraadsleden.

De gebeurtenissen in Haaksbergen bevestigen eerder onderzoek waarin burgemeesters aangaven dat zij met name crises met een grote maatschappelijke impact in combinatie met het afleggen van verantwoording als lastig ervaren vanwege het rollenconflict waar men mee te maken krijgt (Jong, 2017). Een moeilijke opgave waar burgemeesters op dat moment mee worden geconfronteerd, is het vinden van een balans tussen burgervader en bestuurder. Het is niet mogelijk om advies te geven hoe deze balans te vinden. Het enige wat op basis van deze casus kan worden geadviseerd is dat het menselijke aspect niet uit het oog moet worden verloren als men in de rol van bestuurder stapt. Beperk dus het zien en horen van slachtoffers en nabestaanden niet alleen tot de rol van burgervader, maar neem dit ook mee bij het uitoefenen van de rol van bestuurder.

\section{Literatuur}

Baard, L. (2015a, 9 januari) Haaksbergen wijst alle bezwaren en aansprakelijkheid truckdrama af. Twentsche Courant Tubantia.

Baard, L. (2015b, 21 januari) Beslag op alle panden van stuntcoureur. Twentsche Courant Tubantia.

Boin, A., P. 't Hart en A. McConnell (2009) Crisis Exploitation: Political And Policy Impacts of Framing Contests. Journal of European Public Policy, 16(1), 81-106.

Benoit, W.L. (1997) Image Repair Discourse and Crisis Communication. Public Relations Review, 23(2), 177-186.

Bouwhuis, H. (2014a, 1 oktober) Vijf voorlichters versterken Haaksbergen. Communicatie verloopt echter verre van vlekkeloos. Haaksbergen kan het niet alleen. Twentsche Courant Tubantia.

Bouwhuis, H. (2014b, 17 oktober) Halfjaar wachten en niets doen is onbevredigend. Twentsche Courant Tubantia. 
Brändström, A. en S. Kuipers (2003) From 'Normal Incidents' to Political Crises: Understanding The Selective Politicization of Policy Failures. Government and Opposition, 38(3), 279-305.

Colijn, J. (2014a, 29 september) Stuntterrein te krap; 'Hoe kan zoiets worden georganiseerd midden in het dorp?'. De Telegraaf.

Colijn, J. (2014b, 30 september) Zwartepieten is begonnen; Burgemeester: 'Ik wist niet van monstertruck'. De Telegraaf.

Colijn, J. (2014c, 30 september) Tim (5) kreeg geen genoeg van auto's; Jongetje overleden, zusje in kritieke toestand. De Telegraaf.

Colijn, J. (2014e, 28 november) Mario D. al eerder in de fout. De Telegraaf.

Colijn, J. (2015, 21 mei) 'Vergunning afgegeven op automatische piloot'; Rapport: Burgemeester afstandelijk. De Telegraaf.

Coombs, W.T. (2007) Ongoing Crisis Communication. Planning, Managing, And Responding. Thousand Oaks: Sage.

De Telegraaf (2015, 29 mei) 'Schadeclaim truckdrama zo snel mogelijk regelen'; Nieuwe hoop slachtoffers na vertrek burgemeester. De Telegraaf.

de Volkskrant (2014, 30 september) Verdriet, en vraagtekens bij de vergunning. De Volkskrant.

Dohmen, A. en A. Toonen (2014, 29 september) Mocht het publiek te dichtbij?. NRC Handelsblad.

Haaksbergen (z.j.) Onderzoeken en evaluaties monstertruck-drama. www.haaksbergen.nl/ Docs/Inwoners/Actueel/Monstertruckdrama/RAAD-INTERNET\%20Overzicht \%20onderzoeken\%20en\%20evaluaties\%20monstertruck.pdf (geraadpleegd op 5 oktober 2016).

Haaksbergen (2014, 15 oktober) Vergadering Gemeenteraad 15-10-2014. https:// haaksbergen.raadsinformatie.nl/vergadering/131904/Gemeenteraad\%2015-10-2014 (geraadpleegd 17 oktober 2016).

Haaksbergen (2015a, 18 februari) Commissie brengt adviezen uit. www.haaksbergen.nl/4/ Overig/Nieuwsarchief/Commissie-brengt-adviezen-uit.html (geraadpleegd op 6 oktober 2016).

Haaksbergen (2015b) Vergadering Gemeenteraad 27-05-2015, https://haaksbergen. raadsinformatie.nl/vergadering/185457/Gemeenteraad\%2027-05-2015 (geraadpleegd op 24 oktober 2016).

Hart, P. 't (1993) Symbols, Rituals and Power: The Lost Dimensions of Crisis Management. Journal of Contingencies And Crisis Management, 1(1), 36-50.

Hearit, K.M. (2001) Corporate Apologia: When An Organization Speaks in Defense of Itself. In: R.L. Heath en G. Vasquez (red.), Handbook of Public Relations (p. 501-513). Thousand Oaks: Sage Publications.

Hood, C. (2011) The Blame Game. Spin, Bureaucracy, and Self-Preservation in Government. Princeton: Princeton University Press.

Hood, C., W. Jennings, R. Dixon, B. Hogwood en C. Beeston (2009) Testing times: Exploring staged responses and the impact of blame management strategies in two exam fiasco cases. European Journal of Political Research, 48(6), 695-722.

Ihlen, Ø. (2002) Defending The Mercedes A-Class: Combining and Changing Crisis-Response Strategies. Journal of Public Relations Research, 14(3), 185-206.

Jong, W. (2017) Meaning making by public leaders in times of crisis: An assessment. Public Relations Review, 43(5), 1025-1035.

Karsten, N., L. Schaap en F. Hendriks (2014) Krachtig en kwetsbaar. De Nederlandse burgemeester en de staat van een hybride ambt. Bestuurswetenschappen, 68(3), 48-67. 
Karsten, N., L. Schaap en W.J. Verheul (2010) Stijlen van lokaal leiderschap; over burgemeesters, rolopvattingen en verwachtingen. Justitiële verkenningen, 36(3), 31-43.

Louwes, W. (2014, 30 september) Gemeente doet eigen onderzoek naar toedracht ongeval. Twentsche Courant Tubantia.

McGraw, K.M. (1990) Avoiding Blame: An Experimental Investigation of Political Excuses and Justifications. British Journal of Political Science, 20(1), 119-131.

Meerenburgh, J. en M. van Duin (2015) De monstertruck van Haaksbergen. In: M. van Duin en V. Wijkhuijs (red.), Lessen uit crises en mini-crises 2014 (p. 251-264). Den Haag: Boom bestuurskunde.

Nederlands Genootschap van Burgemeesters (2017) De burgemeester als boegbeeld. Crisiscommunicatie op de momenten die ertoe doen. Oldenzaal: Verhaag Drukkerij BV.

NRC Handelsblad (2015, 28 mei) Burgemeester Haaksbergen weg na ongeval met monstertruck. NRC Handelsblad.

NRC Handelsblad (2016, 15 april) 15 maanden cel voor bestuurder monstertruck Haaksbergen. NRC Handelsblad.

Openbaar Ministerie (2015, 9 juni) OM vervolgt chauffeur monstertruck en evenementenorganisatie Haaksbergen. www.om.nl/vaste-onderdelen/zoeken/@89583/vervolgtchauffeur, geraadpleegd op 12 oktober 2016.

Onderzoeksraad voor Veiligheid (2015a) Verkort rapport - Monster truck ongeval Haaksbergen. Tussen vergewissen en vergunnen. Den Haag: Onderzoeksraad voor Veiligheid.

Onderzoeksraad voor Veiligheid (2015b) Monster truck ongeval Haaksbergen. Tussen vergewissen en vergunnen. Den Haag: Onderzoeksraad voor Veiligheid.

Resodihardjo, S.L., B.J. Carroll en C.J.A. van Eijk (2016) Why Traditional responses to Blame Games Fail: The Importance of Context, Rituals, And Sub-Blame Games in The Face of Raves Gone Wrong. Public Administration, 94(2), 350-363.

Rouwenhorst, E. (2014, 16 oktober) Haaksbergen moet nog zeker zes maanden wachten op uitkomst onderzoeken - Veel vragen, nu nog geen antwoorden. Twentsche Courant Tubantia.

Rouwenhorst, E. (2015, 28 mei) Raad toont zo begrip voor slachtoffers. Twentsche Courant Tubantia.

Sackers, H.J.B. (2010) De burgemeester als veiligheidsbaas. Justitiële verkenningen, 36(3), 86-98.

Schreuder, A. en A. Toonen (2014, 1 oktober) Dat stuntteam reed al eerder op het publiek af; Burgemeester zag vergunning niet. NRC Handelsblad.

Talens, H. (2014, 15 oktober) 'Franken trok touwtjes wat strakker aan'. Twentsche Courant Tubantia.

Talens, H. (2015, 18 februari) Vergunning uit de losse pols verleend. Twentsche Courant Tubantia.

Timmers, F. (2014a, 30 september) Garantie veiligheid show was flinterdun. Twentsche Courant Tubantia.

Timmers, F. (2014b, 1 oktober) Onderzoeksraad bijt zich vast in Haaksbergen. Twentsche Courant Tubantia.

Timmers, F. en L. Baard (2014, 11 oktober) Haaksbergen vroeg politie en brandweer ondanks verandering niet om advies - Vergunning show op het laatste moment nog aangepast. Twentsche Courant Tubantia.

Tooms, B. (2014, 16 oktober) Haaksbergen stelt de schuldvraag uit; Documenten online. NRC Handelsblad.

Tubantia (2014a, 29 september) Doden en gewonden bij stunt met monstertruck - Een inktzwarte zondag. Twentsche Courant Tubantia. 
Tubantia (2014b, 1 oktober) Burgemeester Hans Gerritsen heeft vergunning nooit gezien. 'Dat hoefde ook niet'. Amper oog voor veiligheid. Twentsche Courant Tubantia.

Tubantia (2014c, 2 oktober) Komst van monstertruck staat wel in aanvraag van vergunning. Twentsche Courant Tubantia.

Tubantia (2014d, 2 oktober) Veel deelnemers verwacht bij stille tocht. Twentsche Courant Tubantia.

Tubantia (2014e, 4 oktober) Bezwaar slachtoffers tegen vergunning. Twentsche Courant Tubantia.

Tubantia (2014f, 4 oktober) De ontreddering, die vergeet je nooit. Twentsche Courant Tubantia.

Tubantia (2014g, 4 oktober) Te klein voor groot ongeluk. Twentsche Courant Tubantia.

Tubantia (2014h, 10 oktober) 'Gemeente, help de slachtoffers'. Twentsche Courant Tubantia.

Tubantia (2014i, 25 oktober) Noodfonds voor slachtoffers drama. Twentsche Courant Tubantia.

Tubantia (2014j, 22 november) 'Het gas bleef hangen'. Twentsche Courant Tubantia.

Tubantia (2014k, 29 november) Stuntrijder Mario Doornink is niet verzekerd. Twentsche Courant Tubantia.

Tubantia (20141, 29 november) Doornink ontkent, organisatie perplex. Twentsche Courant Tubantia.

Tubantia (2015a, 3 februari) Fonds legt beslag op monstertruck en laat die rijden. Twentsche Courant Tubantia.

Tubantia (2015b, 19 februari) Gerritsen moet spreken. Twentsche Courant Tubantia.

Tubantia (2015c, 11 maart) Gemeente Haaksbergen veegt bezwaren tegen vergunning monstertruck van tafel. - 'Vergunning stuntshow deugt wel'. Twentsche Courant Tubantia.

Tubantia (2015d, 12 maart) COMMENTAAR - Reactie van burgemeester Gerritsen is teleurstellend - Lastig parket. Twentsche Courant Tubantia.

Tubantia (2015e, 21 mei) COMMENTAAR - Positie van burgemeester staat ter discussie Lessen van Haaksbergen. Twentsche Courant Tubantia.

Tubantia (2015f, 21 mei) 'Ik niet geïnteresseerd? Dat zie ik anders'. Twentsche Courant Tubantia.

Tubantia (2015g, 22 mei) Gerritsen verder onder vuur na rapport. Twentsche Courant Tubantia.

Tubantia (2015h, 28 mei) Aftreden onvermijdelijk. Twentsche Courant Tubantia.

Tubantia (2016a, 16 april) Voor Michiel gaat truckdrama nooit meer voorbij. Twentsche Courant Tubantia.

Tubantia (2016b, 30 april) Mario D. in hoger beroep. Twentsche Courant Tubantia. 